\title{
RNA-Binding Protein 4
}

National Cancer Institute

\section{Source}

National Cancer Institute. RNA-Binding Protein 4. NCI Thesaurus. Code C106260.

RNA-binding protein 4 (364 aa, $\sim 40 \mathrm{kDa}$ ) is encoded by the human RBM4 gene. This protein plays a role in alternative splicing, muscle cell differentiation and translation. 